BASIC RESEARCH

\title{
Inhibition of angiotensin II induced endothelin-1 gene expression by 17- $\beta$-oestradiol in rat cardiac fibroblasts
}

\author{
H-H Chao, J-J Chen, C-H Chen, H Lin, C-F Cheng, W-S Lian, Y-L Chen, S-H Juan, J-C Liu, J-Y Liou, \\ $P$ Chan, T-H Cheng
}

Heart 2005;91:664-669. doi: 10.1136/hrt.2003.031898

See end of article for authors' affiliations

Correspondence to:

Correspondence to:
Dr Tzu-Hurng Cheng, Department of Medicine, Taipei Medical UniversityWan Fang Hospital, Taipei, Taiwan; thcheng@ gate.sinica.edu.tw

Accepted 15 July 2004
Objective: To examine whether 17- $\beta$-oestradiol $\left(E_{2}\right)$ may alter angiotensin II (Ang II) induced cell proliferation and to identify the putative underlying signalling pathways in rat cardiac fibroblasts.

Design: Cultured rat cardiac fibroblasts were preincubated with $E_{2}$ then stimulated with Ang II. $\left[{ }^{3} \mathrm{H}\right]$ Thymidine incorporation and endothelin-1 (ET-1) gene expression were examined. The effect of $\mathrm{E}_{2}$ on Ang II induced NADPH oxidase activity, reactive oxygen species (ROS) formation, and extracellular signal regulated kinase (ERK) phosphorylation were tested to elucidate the intracellular mechanism of $E_{2}$ in proliferation and ET-1 gene expression.

Results: Ang II increased DNA synthesis, which was inhibited with $E_{2}(1-100 \mathrm{nmol} / \mathrm{l})$. $\mathrm{E}_{2}$, but not 17- $\alpha$ oestradiol, inhibited Ang II induced ET-1 gene expression as shown by northern blotting and promoter activity assay. This effect was prevented by co-incubation with the oestrogen receptor antagonist $\mathrm{ICl}$ 182780 (1 $\mu \mathrm{mol} / \mathrm{I})$. $\mathrm{E}_{2}$ also inhibited Ang II increased NADPH oxidase activity, ROS formation, ERK phosphorylation, and activator protein-1 mediated reporter activity.

Conclusions: The results suggest that $\mathrm{E}_{2}$ inhibits Ang II induced cell proliferation and ET-1 gene expression, partially by interfering with the ERK pathway through attenuation of ROS generation. Thus, this study provides important new insight regarding the molecular pathways that may contribute to the proposed beneficial effects of oestrogen on the cardiovascular system.
$\mathrm{O}$ estrogen has been reported to have cardioprotective and antihypertensive effects in premenopausal women. 17- $\beta$-Oestradiol $\left(\mathrm{E}_{2}\right)$ is the terminal biologically active natural oestrogen with the highest affinity to the oestrogen receptor. $\mathrm{E}_{2}$ has been reported to inhibit low density lipoproteins peroxidation in vitro, ${ }^{1}$ to an even larger extent than vitamin E does. ${ }^{2}$ Besides lipid modifying effects, $\mathrm{E}_{2}$ exerts its potentially vasoprotective effects through decreased vascular oxidative stress. ${ }^{3}{ }^{4}$ Laufs and colleagues reported that $E_{2}$ inhibits vascular reactive oxygen species (ROS) production by downregulating Racl GTPase in vascular smooth muscle cells. ${ }^{5}$ Furthermore, $E_{2}$ is reported to exert radical scavenging effects through the regulation of radical scavenging enzyme activity and expression in the vascular cells. ${ }^{6}$ Thus, it is reasonable to propose that the cardioprotective effect of $\mathrm{E}_{2}$ may be related to its antioxidant properties; however, this hypothesis remains to be tested.

Angiotensin II (Ang II), the effector peptide of the reninangiotensin system, is now known to have growth promoting properties in various cell types and a mitogenic effect on cardiac fibroblasts..$^{7-9}$ Recent reports have shown that Ang II stimulates membrane bound NADPH oxidase, which generates ROS in cardiac fibroblasts. ${ }^{10}$ We recently reported that ROS are essential for Ang II induced proliferation and endothelin-1 (ET-1) gene expression in cardiac fibroblasts. ${ }^{11}$ However, whether $E_{2}$ inhibits Ang II induced cell proliferation and ET-l gene induction by attenuating ROS generation in cardiac fibroblasts remains unclear. This study was conducted to examine whether $E_{2}$ inhibits Ang II induced ET-1 gene expression and to identify signalling protein kinase cascades that may be responsible for the putative effect of oestrogen.

\section{METHODS}

\section{Materials}

Dulbecco's modified Eagle's medium (DMEM), fetal calf serum, and tissue culture reagents were obtained from Life
Technologies, Inc. A rat ET-1 cDNA probe (accession No M64711) was obtained as previously described. ${ }^{12}$ A full length of the ET-1 promoter region $(4.4 \mathrm{~kb})$ was fused to the chloramphenicol acetyltransferase (CAT) reporter gene. ${ }^{11}$ PBLCAT2 (containing CAT reporter gene with its promoter) and PBLCAT3 (containing the CAT gene only) were constructed as previously described. ${ }^{13} 2^{\prime}, 7^{\prime}$-Dichlorofluorescein diacetate was obtained from Molecular Probes (Eugene, Oregon, USA). $\mathrm{H}_{2} \mathrm{O}_{2}$ was purchased from Acros Organics (Pittsburgh, Pennsylvania, USA). $\mathrm{E}_{2}, N$-acetylcysteine (NAC), and all other reagent grade chemicals were purchased from the Sigma Chemical Co (St Louis, Missouri, USA). ICI 182780 was purchased from Tocris Cookson (Ballwin, Missouri, USA). The plasmid activator protein-1 (AP-1) luciferase containing the firefly luciferase reporter gene driven by a basic promoter element (TATA box) joined to tandem repeats of AP-1 binding element were obtained from Stratagene (La Jolla, California, USA).

\section{Culture of cardiac fibroblasts}

The investigation was conducted in accordance with the Guide for the care and use of laboratory animals published by the National Institutes of Health in the United States (NIH Publication No 85-23, revised 1996) and approved by the institutional animal care and use committee of Taipei Medical University. Primary cultures of neonatal rat cardiac fibroblasts were prepared as previously described. ${ }^{11}$ Cardiac fibroblasts grown in either 60 or $100 \mathrm{~mm}$ culture dishes from the second to fourth passage were used for the experiments. The purity of the fibroblasts was $>95 \%$ as determined by

\footnotetext{
Abbreviations: Ang II, angiotensin II; AP-1, activator protein-1; $\mathrm{AT}_{1}$, angiotensin II subtype 1; CAT, chloramphenicol acetyltransferase; DMEM, Dulbecco's modified Eagle's medium; DPI, diphenyliodonium; $E_{2}$, 17- $\beta$-oestradiol; ERK, extracellular signal regulated kinase; ET-1, endothelin-1; NAC, N-acetylcysteine; ROS, reactive oxygen species
} 

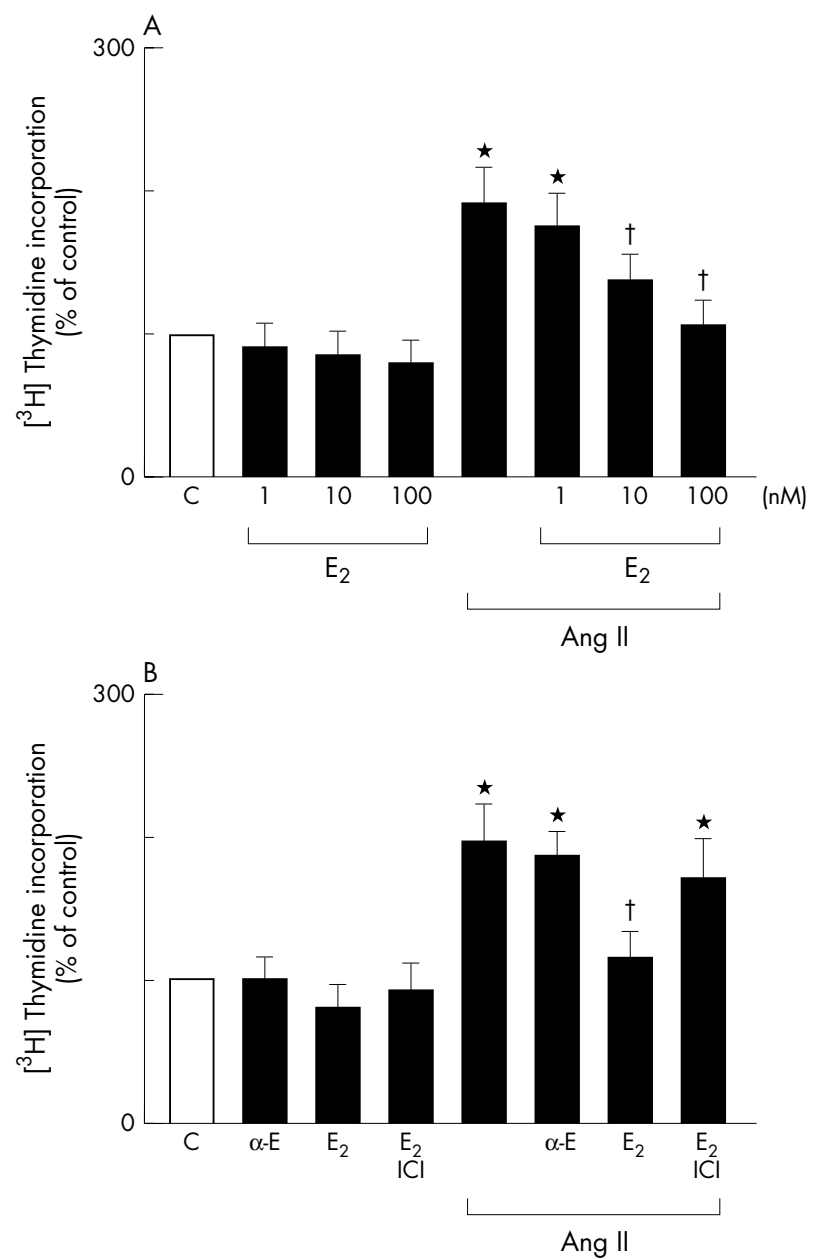

Figure 1 Effects of 17- $\beta$-oestradiol $\left(E_{2}\right)$ on angiotensin II (Ang II) induced cell proliferation in cardiac fibroblasts. All experiments were performed by incorporation of $\left[{ }^{3} \mathrm{H}\right]$ thymidine into DNA. Increases in $\left[{ }^{3} \mathrm{H}\right]$ thymidine incorporation are each expressed relative to the $\left[{ }^{3} \mathrm{H}\right]$ content $(100 \%)$ in their respective drug-free controls (C). All data are shown as the mean (SEM) for triplicate determinations for six cell preparations. ${ }^{*} p<0.05 \vee C ;+p<0.05 \vee$ Ang II alone. (A) $E_{2}$ inhibits Ang II induced DNA synthesis. Cells were preincubated with the indicated doses of $E_{2}$ and treated with Ang $I I(100 \mathrm{nmol} / \mathrm{l})$ for 24 hours. $\left[{ }^{3} \mathrm{H}\right]$ thymidine incorporation was then assayed. (B) Effects of the oestrogen receptor antagonist ICl 182780 (ICl) on $\mathrm{E}_{2}$ mediated inhibition of Ang II induced DNA synthesis and lack of effect of 17- $\alpha$ oestradiol $(\alpha-E)$ on Ang II induced DNA synthesis. Cells were preincubated with $\alpha-E(100 \mathrm{nmol} / \mathrm{l}), \mathrm{E}_{2}(100 \mathrm{nmol} / \mathrm{l})$, or the combination of $E_{2}$ plus $I C I(1 \mu \mathrm{mol} / /)$ followed by either the application of Ang II (100 nmol/l) for 24 hours or its absence.

morphological characterisation and by immunostaining with antibodies to von Willebrand factor VIII. Cardiac fibroblasts were grown in DMEM without phenol red containing antibiotics and 10\% fetal calf serum until 24 hours before experimentation, when cells were placed in a defined serumfree medium containing insulin $(0.5 \mu \mathrm{mol} / \mathrm{l})$ and transferrin $(5 \mathrm{mg} / \mathrm{ml})$ for all experiments. Cells were then preincubated with $E_{2}$ for 12 hours and then with or without Ang II $(100 \mathrm{nmol} / \mathrm{l})$ for various incubation times as indicated, followed by harvesting. Cellular viability under all treatment conditions was determined by cell count, morphology, and trypan blue exclusion.

\section{DNA synthesis}

To measure synthesis of new DNA, cells $\left(1 \times 10^{5} /\right.$ well $)$ were plated in six-well $(35 \mathrm{~mm})$ dishes 24 hours before experiments as previously described. ${ }^{14}$ Cells were incubated with $\left[{ }^{3} \mathrm{H}\right]$ thymidine $(5 \mu \mathrm{Ci} / \mathrm{ml})$. After the indicated treatment, cells were harvested by incubation at $4^{\circ} \mathrm{C}$ with trichloroacetic acid (5\%) followed by solubilisation in a 1/10th normal $\mathrm{NaOH}$ solution. Radioactivity was determined by scintillation counting. Data are presented as the mean (SEM) of 9-12 determinations for three to four cell preparations and normalised to the untreated sample $\times 100$ (that is, the percentage of control).

\section{NADPH oxidase activity assay}

NADPH oxidase was measured in cardiac fibroblasts as described previously. ${ }^{15}$
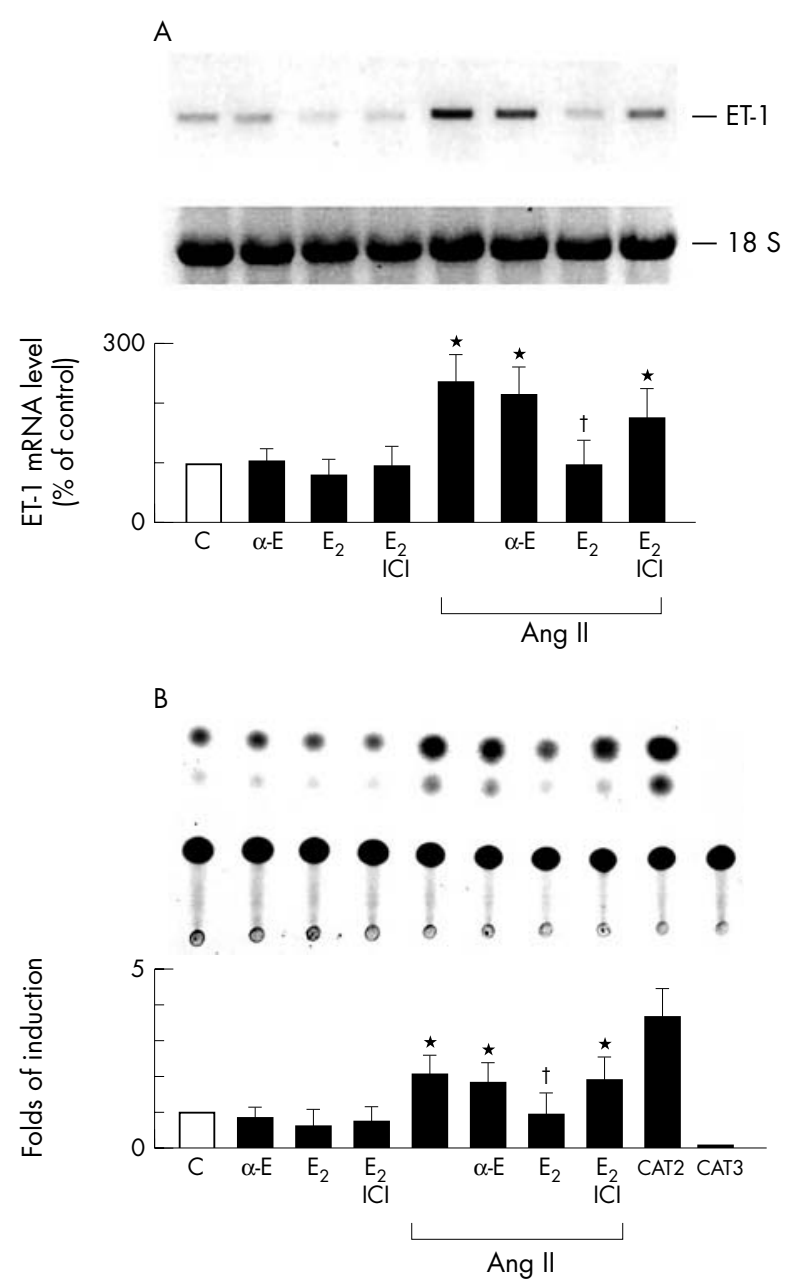

Figure $2 E_{2}$ down regulates Ang II induced endothelin-1 (ET-1) gene expression in cardiac fibroblasts. The results are shown as the mean (SEM) $(n=6)$. ${ }^{*} p<0.05 \vee C ; \uparrow p<0.05 \vee$ Ang ll alone.

(A) Downregulation of Ang II induced ET-1 mRNA by $E_{2}$. Cells were preincubated with $\alpha-E(100 \mathrm{nmol} / \mathrm{l}), E_{2}(100 \mathrm{nmol} / \mathrm{l})$, or the combination of $\mathrm{E}_{2}$ plus $\mathrm{ICl}(1 \mu \mathrm{mol} / \mathrm{l})$ and then stimulated with Ang II (100 nmol/l) for 30 minutes or not. Total RNA was extracted and northern hybridisation was performed with ${ }^{32} \mathrm{P}$ labelled ET- 1 as a probe. 18S RNA was used to normalise the RNA applied in each lane. Data are presented as percentage changes of experimental groups compared with untreated C. (B) $E_{2}$ inhibits Ang II induced ET-1 promoter activity. Cells were transfected with chimeric chloramphenicol acetyltransferase (CAT) fusion genes and preincubated with $\alpha-E(100 \mathrm{nmol} / \mathrm{l}), \mathrm{E}_{2}$ $(100 \mathrm{nmol} / \mathrm{l})$, or the combination of $\mathrm{E}_{2}$ plus $\mathrm{ICl}(1 \mu \mathrm{mol} / \mathrm{l})$ and then stimulated with Ang II (100 nmol/l) for 24 hours or not. Cells were harvested and CAT activities were measured. CAT activities after normalising to activities of $\beta$-galactosidase are shown as activity relative to C. CAT2 and CAT3 are positive and negative controls, respectively. 


\section{Detection of intracellular ROS}

Intracellular ROS formation in cardiac fibroblasts was measured by monitoring changes in dichlorofluorescein fluorescence as described previously. ${ }^{16}$ Chemiluminescence of superoxide production was assayed as described previously. ${ }^{17}$

\section{RNA isolation and northern blot analysis}

Total RNA and northern blot analyses of ET-1 and 18S RNA were prepared as described previously. ${ }^{11}$

\section{Transfection and CAT assays}

For the transient transfections, cells were transfected with various expression vectors by the calcium phosphate method..$^{13}$ For the transient transfections, cardiac fibroblasts were transfected with various expression vectors by the calcium phosphate method. DNA concentration for all samples was adjusted to an equal amount in each experiment. Briefly, cardiac fibroblasts were maintained in culture for 24 hours before transfection. The indicated expression vectors were mixed with calcium phosphate and immediately added to the cardiac fibroblast cell culture. After incubation for five hours, cells were washed three times with phosphate buffered saline and incubated with 10\% serum DMEM. After 12 hours, cells were washed with serum-free media and further incubated for 48 hours in serum-free medium. To correct for variability in transfection efficiency, $5 \mu \mathrm{g}$ of pSV$\beta^{\prime}$-galactosidase plasmid DNA was co-transfected in all the experiments. CAT and $\beta$-galactosidase were assayed as described previously. ${ }^{13}$

\section{Western blot analysis}

Rabbit polyclonal phospho-specific extracellular signal regulated kinase (ERK) antibodies were purchased from New England Biolabs (Beverly, Massachusetts, USA). ERK antibodies were purchased from Santa Cruz Biotechnology Inc (Santa Cruz, California, USA). Western blot analysis was performed as previously described. ${ }^{16}$

\section{Luciferase assay}

Cardiac fibroblasts plated on six-well $(35 \mathrm{~mm})$ dishes were transfected with the luciferase reporter construct possessing consensus AP-1 binding sites (AP-1-luciferase) (Stratagene). After incubation for 24 hours in serum-free DMEM, cardiac fibroblasts were cultured under various conditions as indicated for 48 hours and then assayed for luciferase activity with a luciferase reporter assay kit (Stratagene). As was the case for AP-1 transcriptional activity, the specific firefly luciferase activity was normalised for transfection efficiency to its respective $\beta$-galactosidase activity and expressed relative to the control.

\section{Statistical analysis}

Results are expressed as mean (SEM) for at least six experiments unless designated otherwise. Data were analysed with Student's $t$ test and analysis of variance followed by a Dunnett multiple comparison test with GraphPad Prism (GraphPad Software, San Diego, California, USA). A probability value of $p<0.05$ was considered to be significant.

\section{RESULTS}

\section{Effects of $E_{2}$ on Ang II induced cell proliferation of cardiac fibroblasts}

The effects of $\mathrm{E}_{2}$ on Ang II stimulated rat cardiac fibroblast proliferation was assessed by analysing DNA synthesis with $\left[{ }^{3} \mathrm{H}\right]$ thymidine incorporation. Preincubation of cardiac fibroblast $s$ with $E_{2}$ for 12 hours $(1-100 \mathrm{nmol} / \mathrm{l})$ followed by exposure to $E_{2}$ with Ang II ( $100 \mathrm{nmol} / \mathrm{l}$ ) for 24 hours resulted in a concentration dependent decrease in Ang II induced cell proliferation (fig lA). Unlike $\mathrm{E}_{2}, 17$ - $\alpha$-oestradiol ( $100 \mathrm{nmol} / \mathrm{l}$ ) had no effect on Ang II induced cell proliferation, whereas preincubation with the oestrogen receptor antagonist ICI $182780(1 \mu \mathrm{mol} / \mathrm{l})$ prevented $\mathrm{E}_{2}$ mediated downregulation of Ang II induced cell proliferation (fig 1B). These data clearly suggest that $\mathrm{E}_{2}$ inhibits Ang II induced cell proliferation of cardiac fibroblasts.

\section{Effects of $E_{2}$ on Ang II induced ET- 1 gene expression in} cardiac fibroblasts

Northern blot analysis was used to examine whether $\mathrm{E}_{2}$ inhibits Ang II increased ET-1 mRNA concentrations in cardiac fibroblasts (fig 2A). Cardiac fibroblasts were preincubated with $\mathrm{E}_{2}$ ( $100 \mathrm{nmol} / \mathrm{l}, 12$ hours $)$, treated with Ang II $(100 \mathrm{nmol} / \mathrm{l})$ for 30 minutes, then assayed for $E_{2}$ inhibited Ang II induced ET-1 mRNA expression. Unlike $E_{2}, 17-\alpha-$ oestradiol ( $100 \mathrm{nmol} / \mathrm{l})$ had no effect on Ang II induced ET- 1 mRNA, whereas preincubation with the oestrogen receptor antagonist ICI $182780(1 \mu \mathrm{mol} / \mathrm{l})$ prevented $\mathrm{E}_{2}$ mediated downregulation of Ang II induced ET-1 mRNA (fig 2A). To determine whether $E_{2}$ inhibition of Ang II induced ET-1 expression is regulated at the transcriptional level, an ET-l promoter construct containing the ET-1 promoter region $(-4.4 \mathrm{~kb})$ and the reporter gene CAT was constructed and transiently transfected into cardiac fibroblasts. Exposure of cardiac fibroblasts to Ang II $(100 \mathrm{nmol} / \mathrm{l})$ for 24 hours significantly increased ET-1 promoter activity (fig 2B). Preincubation of cardiac fibroblasts with $\mathrm{E}_{2}$ ( $\left.100 \mathrm{nmol} / \mathrm{l}\right)$ inhibited Ang II induced ET-1 promoter activity. Unlike $\mathrm{E}_{2}$, 17 - $\alpha$-oestradiol ( $100 \mathrm{nmol} / \mathrm{l})$ had no effect on Ang II induced ET-1 promoter activity, whereas the preincubation of cardiac fibroblasts with the oestrogen receptor antagonist ICI $182780(1 \mu \mathrm{mol} / \mathrm{l})$ prevented $\mathrm{E}_{2}$ mediated downregulation of Ang II induced ET-1 promoter activity (fig 2B). These data indicate that $\mathrm{E}_{2}$ inhibits Ang II induced ET-1 gene expression in cardiac fibroblasts.

\section{Effects of $E_{2}$ on Ang II increased NADPH oxidase activity and ROS formation}

We have shown that Ang II stimulates ROS production in cardiac fibroblasts. ${ }^{11}$ In this study, we further examined whether $\mathrm{E}_{2}$ prevents Ang II increased NADPH oxidase activity and ROS formation in cardiac fibroblasts. Cardiac fibroblasts were pretreated with $E_{2}(1-100 \mathrm{nmol} / \mathrm{l}, 12$ hours $)$, then treated with Ang II ( $100 \mathrm{nmol} / \mathrm{l})$. Preincubation of cultured cardiac fibroblasts with $\mathrm{E}_{2}(1-100 \mathrm{nmol} / \mathrm{l})$ significantly inhibited Ang II induced NADPH oxidase activity and ROS formation as measured after Ang II treatment for 30 minutes (fig 3A, B, C). Pretreatment of cultured cardiac fibroblasts with $\mathrm{E}_{2}(100 \mathrm{nmol} / \mathrm{l})$, NAC $(10 \mathrm{mmol} / \mathrm{l})$, or diphenyliodonium (DPI) $(10 \mu \mathrm{mol} / \mathrm{l})$ significantly inhibited Ang II induced ROS concentrations (fig 3D). Preincubation with the oestrogen receptor antagonist ICI 182780 ( $1 \mu \mathrm{mol} / \mathrm{l}$ ) also prevented the inhibitory effect of $\mathrm{E}_{2}$ (fig $3 \mathrm{~B}$ ). These findings support our earlier comments that $\mathrm{E}_{2}$ inhibits Ang II increased NADPH oxidase activity and intracellular ROS concentrations in cardiac fibroblasts.

\section{Effects of $E_{2}$ on Ang II activated ERK phosphorylation and AP- 1 mediated reporter activity in cardiac fibroblasts}

Ang II has previously been shown to activate ERK, and the activation of this pathway is redox sensitive. ${ }^{11}$ We recently reported that ROS were involved in the activation of the ERK pathway, which culminated in ET-1 gene expression. ${ }^{11}{ }^{14}$ To gain insight into the mechanism of action of $E_{2}$, we examined whether $E_{2}$ affects the Ang II activated ERK pathway of cardiac fibroblasts. We examined the effect of $E_{2}$ and antioxidants on Ang II induced ERK phosphorylation. As 

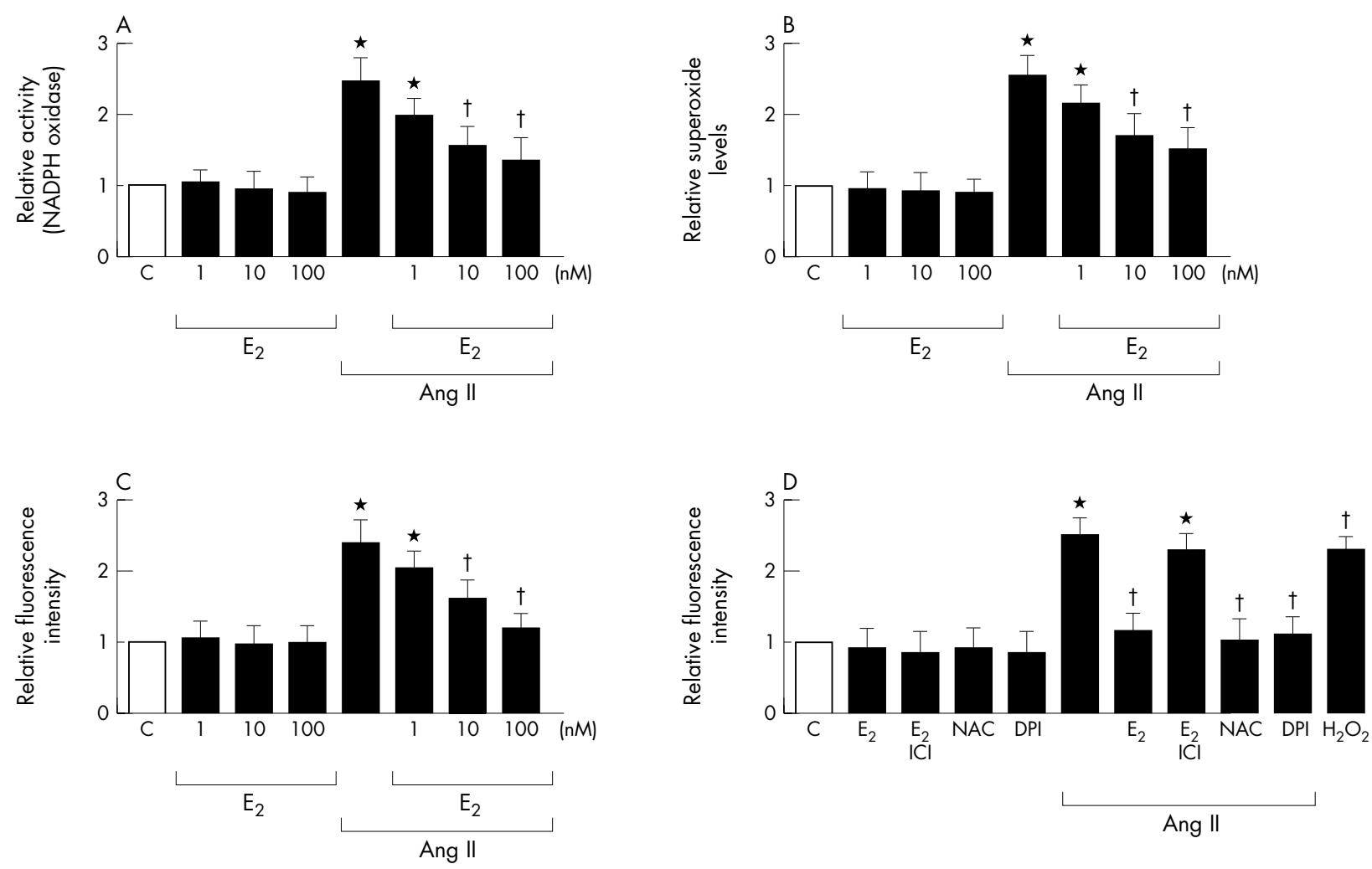

Figure 3 Effects of $E_{2}$ on Ang II increased NADPH oxidase activity and reactive oxygen species (ROS) formation. Cells were preincubated with $E_{2}$ (1-100 nmol/l) for 12 hours and then stimulated with Ang II (100 nmol/l) for 30 minutes or not. * $\mathrm{p}<0.05 v \mathrm{C} ; \mathrm{tp}<0.05 v$ Ang II alone. (A) Effect of $\mathrm{E}_{2}$ (1-100 nmol/I) on Ang II increased NADPH oxidase activity. Cardiac fibroblasts after treatment were lysed and immediately assayed for NADPH oxidase activity. (B) Effect of $E_{2}(1-100 \mathrm{nmol} / \mathrm{I})$ on Ang II induced superoxide formation. Cardiac fibroblasts after treatment were lysed and immediately assayed for superoxide by the lucigenin method. (C) Effect of $E_{2}(1-100 \mathrm{nmol} / \mathrm{I})$ on Ang II induced ROS generation. Fluorescent intensities of dichlorofluorescein showed that intracellular ROS concentrations were increased by Ang II. (D) Effects of $E_{2}, E_{2}$ plus ICI, or antioxidants on Ang II induced ROS generation. Cells were preincubated with $\mathrm{E}_{2}(100 \mathrm{nmol} / \mathrm{l})$, the combination of $\mathrm{E}_{2}$ plus $\mathrm{ICl}(1 \mu \mathrm{mol} / \mathrm{l})$, or the antioxidant $\mathrm{N}$-acetylcysteine (NAC) (10 mmol/l) or diphenyliodonium (DPI) $(10 \mu \mathrm{mol} / \mathrm{l})$ and then stimulated with Ang II (100 nmol/l) for 30 minutes or not. $\mathrm{H}_{2} \mathrm{O}_{2}(100 \mu \mathrm{mol} / \mathrm{l})$ was used as a positive control.

fig 4A shows, exposure of cardiac fibroblasts to Ang II ( $100 \mathrm{nmol} / \mathrm{l}$ ) for 30 minutes rapidly activated phosphorylation of ERK. However, cardiac fibroblasts pretreated with $\mathrm{E}_{2}$ ( $100 \mathrm{nmol} / \mathrm{l}, 12$ hours) and then with Ang II ( $100 \mathrm{nmol} / \mathrm{l}$ ) for 30 minutes had significantly decreased levels of Ang II induced ERK phosphorylation. Pretreatment of cardiac fibroblasts with the antioxidant NAC ( $10 \mathrm{mmol} / \mathrm{l}, 30 \mathrm{~min}-$ utes) or DPI ( $10 \mu \mathrm{mol} / \mathrm{l}, 30$ minutes $)$ also significantly decreased Ang II induced ERK phosphorylation. Moreover, Ang II increased AP-1 activation is involved in ET-1 gene induction. ${ }^{11}$ We further evaluated the effects of $E_{2}$ on Ang II induced AP-1 functional activity with a reporter gene assay. $\mathrm{E}_{2}(100 \mathrm{nmol} / \mathrm{l}), \mathrm{NAC}(10 \mathrm{mmol} / \mathrm{l})$, or DPI $(10 \mu \mathrm{mol} / \mathrm{l})$ significantly attenuated Ang II induced AP-1 mediated reporter activation (fig 4B). These findings show that $E_{2}$ inhibits the Ang II activated ERK signalling pathway and AP- 1 activation, which is compatible with antioxidant action in cardiac fibroblasts.

\section{DISCUSSION}

Neonatal cardiac fibroblasts were used in these experiments, and it is possible that different results might have been obtained had adult cardiac fibroblasts been used. However, we have previously shown that ROS mediates Ang II induced proliferation and ET-1 gene expression in neonatal rat cardiac fibroblasts. ${ }^{14}$ Furthermore, neonatal fibroblasts have properties (that is, $\left[{ }^{3} \mathrm{H}\right]$ proline incorporation and production of both matrix metalloproteinases and metalloproteinases) relevant to extracellular matrix turnover in the postmyocardial infarction heart. ${ }^{18}$

From several epidemiological studies, $\mathrm{E}_{2}$ is thought to have a protective effect against left ventricular hypertrophy, which is an important cardiovascular risk factor for morbidity and mortality. ${ }^{19-21}$ Premenopausal women have a lower prevalence of left ventricular hypertrophy than their age matched male counterparts. ${ }^{19}$ Left ventricular mass is significantly greater in men than in women even after indexing for body surface area. $^{20}{ }^{21}$ Experimental studies have shown cardioprotective roles of $\mathrm{E}_{2}{ }^{22-25}$; however, the direct effect of $\mathrm{E}_{2}$ on cardiac cell growth remains controversial. Previous studies have shown that the exogenous administration of $E_{2}$ alone either decreased, ${ }^{22}$ increased ${ }^{26}$ or had no effect on DNA synthesis in cultured cardiac fibroblasts. ${ }^{27}{ }^{28}$ In this study, we clearly showed that $\mathrm{E}_{2}$ modulates Ang II induced cell proliferation and ET-l gene expression in cardiac fibroblasts. Increased ROS concentrations are involved in cell proliferation and ET-1 induction, which can be attenuated by antioxidant pretreatment of cells. ${ }^{11}{ }^{14}$ In agreement with previous studies in other cell types, ${ }^{5} 29$ we have shown that $E_{2}$ inhibits Ang II mediated ROS release in cardiac fibroblasts. More specifically, $\mathrm{E}_{2}$ prevented Ang II mediated NADPH oxidase activity but did not significantly reduce ROS after transfection with the active RacL61, ${ }^{5}$ pointing towards a role of Racl in the antioxidative effects of $\mathrm{E}_{2}$. Indeed, Laufs and colleagues ${ }^{5}$ also showed that $\mathrm{E}_{2}$ downregulated Racl protein and mRNA expression in a concentration and time dependent manner, both alone and in the presence of Ang II. Similarly, $E_{2}$ 
A
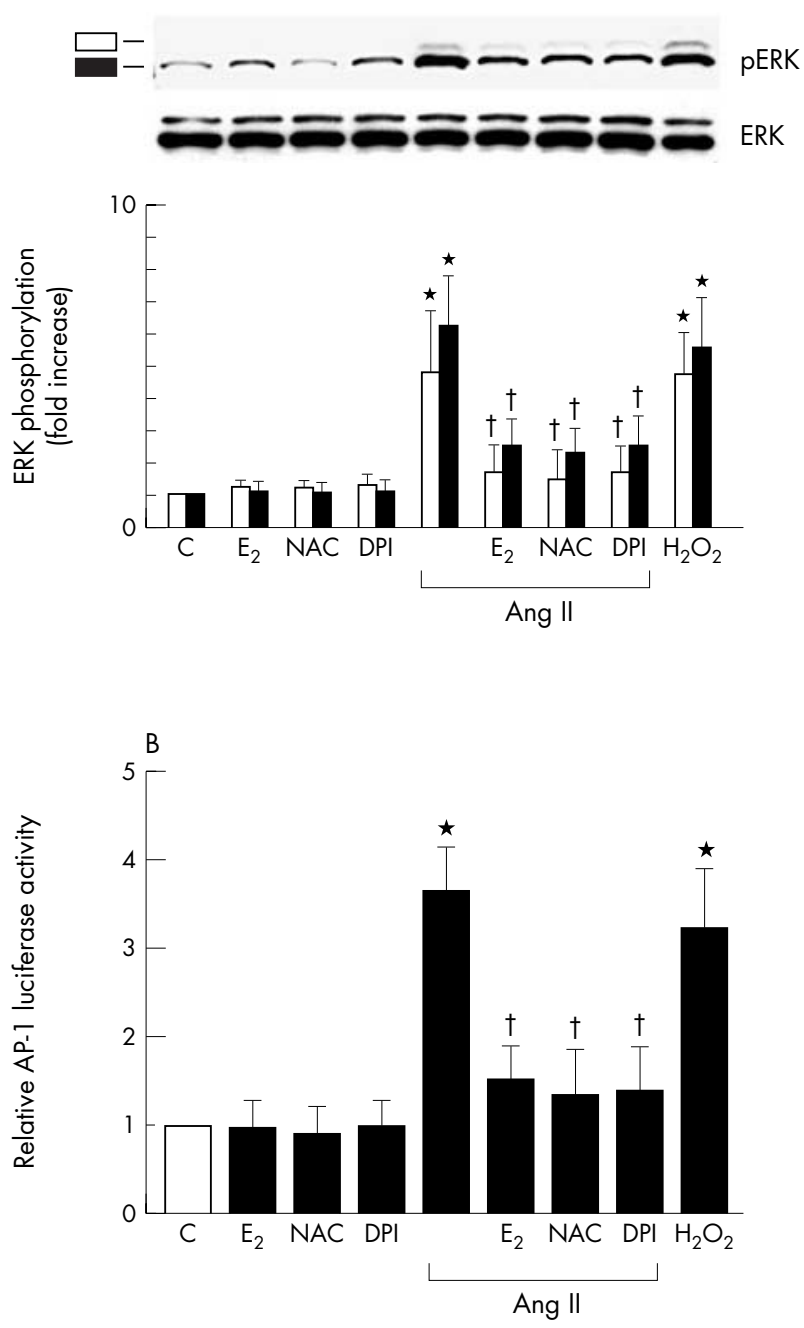

Figure 4 Inhibitory effect of $E_{2}$ on Ang II increased extracellular signal regulated kinase (ERK) phosphorylation and activator protein 1 (AP-1) mediated reporter activity in cardiac fibroblasts. Results are shown as the mean (SEM) $(n=6)$. ${ }^{*} p<0.05 v$ control; $+p<0.05 v$ Ang II alone. (pERK, phosphorylated ERK.) (A) Effects of $E_{2}, E_{2}$ plus ICl, or various antioxidants on Ang II increased ERK phosphorylation. Cells were preincubated with $\mathrm{E}_{2}(100 \mathrm{nmol} / \mathrm{l})$, NAC $(10 \mathrm{mmol} / \mathrm{l})$, or DPI $(10 \mu \mathrm{mol} / \mathrm{l})$ and then stimulated with Ang II (100 nmol/l/) for 30 minutes. $\mathrm{E}_{2}, \mathrm{NAC}$, or DPI inhibited Ang II induced phosphorylation of ERK. $\mathrm{H}_{2} \mathrm{O}_{2}$ $(100 \mu \mathrm{mol} / \mathrm{l})$ was used as a positive control. Phosphorylation of ERK was detected by western blotting with phospho-ERK antibody. Density was measured with a densitometer. Data are shown as fold increase relative to control groups. (B) Effects of $E_{2}, E_{2}$ plus $\mathrm{ICl}$, or various antioxidants on Ang II increased AP-1 mediated reporter activity. Cardiac fibroblasts, transfected with AP-1-luciferase, were treated as indicated. Cells were preincubated with $E_{2}(100 \mathrm{nmol} / \mathrm{I})$, the combination of $E_{2}$ plus $\mathrm{ICI}$ $(1 \mu \mathrm{mol} / \mathrm{l})$, or the antioxidant NAC $(10 \mathrm{mmol} / \mathrm{l})$ or DPI $(10 \mu \mathrm{mol} / \mathrm{l})$ and then stimulated with Ang II $(100 \mathrm{nmol} / \mathrm{l})$ for 24 hours or not. $\mathrm{H}_{2} \mathrm{O}_{2}$ $(100 \mu \mathrm{mol} / \mathrm{l})$ was used as a positive control. Luciferase activity was expressed as activity relative to untreated $C$.

inhibited basal and Ang II stimulated Racl activity. Downregulation of Racl expression by $E_{2}$ was completely blocked in the presence of the non-selective oestrogen receptor antagonist ICI $182780,{ }^{5}$ indicating that the event was receptor mediated. In particular, it has been shown that activation of ERK is redox sensitive ${ }^{10} 3031$ and that suppression of ROS inhibits ET-1 gene expression. ${ }^{11}{ }^{14}$ One possible explanation for the inhibitory effect of $E_{2}$ on Ang II induced cell proliferation and ET-1 gene expression may thus be the ability of $E_{2}$ to attenuate ROS formation and then inhibit
ERK phosphorylation and AP-1 mediated reporter activity in cardiac fibroblasts. Alternatively, $\mathrm{E}_{2}$ may inhibit Ang II induced cell proliferation and ET-1 gene expression by the increase of radical scavenging enzyme activity and expression. ${ }^{6}$ Although the effects of oestrogen in vitro on cardiac Ang II subtype $\mathrm{l}\left(\mathrm{AT}_{1}\right)$ receptor expression are not known, several studies have shown an alteration in Ang II receptor expression or binding with changes in circulating oestrogen concentrations in vivo. ${ }^{32}$ In vascular smooth muscle cells, oestrogen acts on the renin-angiotensin system at different points of the cascade: at the formation of Ang II, at the level of Ang II receptors, and on Ang II induced responses. Oestrogen has been shown to increase gene expression and plasma concentrations of angiotensinogen. Oestrogen deficiency has been shown to increase $\mathrm{AT}_{1}$ receptor mRNA concentrations, as well as the efficacy of Ang II in vasoconstriction (due to increased $\mathrm{AT}_{1}$ receptor density), whereas oestrogen replacement therapy in ovariectomised rats reversed $\mathrm{AT}_{1}$ receptor overexpression. ${ }^{29}$ Clarification of whether oestradiol affects the number of angiotensin receptors or angiotensin binding to its receptors may shed light on the mechanisms of oestradiol effects in fibroblasts. Thus, further experiments will be necessary to identify the detailed mechanisms of the inhibitory effects of $E_{2}$ on Ang II induced ET-1 gene expression in cardiac fibroblasts.

The present study delivers important new insight into the molecular mechanisms of action of $\mathrm{E}_{2}$ in cardiac fibroblasts. Moreover, our results show that $\mathrm{E}_{2}$ suppresses the ERK pathway and reduces Ang II induced cell proliferation and ET-1 gene expression. It appears plausible that the Ang II activated signalling pathway consists of a number of redox sensitive steps and that $\mathrm{E}_{2}$ treatment may modulate the redox state of the cell.

In summary, this study has shown that $\mathrm{E}_{2}$ inhibits Ang II induced ROS formation, ERK phosphorylation, AP-1 mediated reporter activity, ET-1 gene expression, and cell proliferation in cardiac fibroblasts. These findings support the proposed beneficial effects of oestrogen in the cardiovascular system.

\section{ACKNOWLEDGEMENTS}

This study was supported by grants from Shin Kong Wu Ho-Su Memorial Hospital (SKH-TMU-92-15 to T-H Cheng and H-H Chao; SKH-TMU-93-03 to J-C Liu and J-Y Liou).

\section{Authors' affiliations}

H-H Chao*, S-H Juan, J-C Liv***, P Chan ***, Graduate Institute of Medical Science, Taipei Medical University, Taipei, Taiwan J-Y Liou, Shin Kong Wu Ho-Su Memorial Hospital, Taipei J-J Chen**, Y-L Chen**, Department of Internal Medicine, National Taiwan University Hospital and National Taiwan University College of Medicine, Taipei

C-H Chen ${ }^{* * *}$, C-F Cheng, W-S Lian, Institute of Biomedical Sciences, Academia Sinica, Taipei

T-H Cheng, Department of Medicine, Taipei Medical University-Wan Fang Hospital, Taipei

H Lin, Department of Medicine, Taipei Medical University Hospital, Taipei

*Also the Shin Kong Wu Ho-Su Memorial Hospital, Taipei **Also the Institute of Biomedical Sciences, Academia Sinica, Taipei ***Also the Department of Medicine, Taipei Medical University-Wan Fang Hospital, Taipei

\section{REFERENCES}

1 Rifici VA, Khachadurian AK. The inhibition of low-density lipoprotein oxidation by 17-beta estradiol. Metabolism 1992;41:1110-4.

2 Ayres S, Tang M, Subbiah MT. Estradiol-17beta as an antioxidant: some distinct features when compared with common fat-soluble antioxidants. J Lab Clin Med 1996;128:367-75.

3 Hong MK, Romm PA, Reagan K, et al. Effects of estrogen replacement therapy on serum lipid values and angiographically defined coronary artery disease in postmenopausal women. Am J Cardiol 1992;69:176-8. 
4 Mendelsohn ME, Karas RH. The protective effects of estrogen on the cardiovascular system. N Engl J Med 1999;340:1801-11.

5 Laufs U, Adam O, Strehlow K, et al. Down-regulation of Rac-1 GTPase by estrogen. J Biol Chem 2003;278:5956-62

6 Strehlow K, Rotter S, Wassmann S, et al. Modulation of antioxidant enzyme expression and function by estrogen. Circ Res 2003;93:170-7.

7 Fujisaki $\mathrm{H}$, Ito $\mathrm{H}$, Hirata $\mathrm{Y}$, et al. Natriuretic peptides inhibit angiotensin IIinduced proliferation of rat cardiac fibroblasts by blocking endothelin-1 gene expression. J Clin Invest 1995;96:1059-65.

8 Gray MO, Long CS, Kalinyak JE, et al. Angiotensin II stimulates cardiac myocyte hypertrophy via paracrine release of TGF-beta 1 and endothelin-1 from fibroblasts. Cardiovasc Res 1998;40:352-63.

9 Crabos M, Roth M, Hahn AW, et al. Characterization of angiotensin II receptors in cultured adult rat cardiac fibroblasts: coupling to signaling systems and gene expression. J Clin Invest 1994;93:2372-8.

10 Sano M, Fukuda K, Sato T, et al. ERK and p38 MAPK, but not NF-kappaB, are critically involved in reactive oxygen species-mediated induction of IL- 6 by angiotensin II in cardiac fibroblasts. Circ Res 2001;89:661-9.

11 Mervaala EM, Cheng ZJ, Tikkanen I, et al. Endothelial dysfunction and xanthine oxidoreductase activity in rats with human renin and angiotensinogen genes. Hypertension 2001;37:414-8.

12 Deng AY, Dene H, Pravenec M, et al. Genetic mapping of two new blood pressure quantitative trait loci in the rat by genotyping endothelin system genes. J Clin Invest 1994:93:2701-9.

13 Cheng TH, Shih NL, Chen SY, et al. Reactive oxygen species modulate endothelin-l-induced c-fos gene expression in cardiomyocytes. Cardiovasc Res 1999;41:654-62.

14 Cheng TH, Cheng PY, Shih NL, et al. Involvement of reactive oxygen species in angiotensin II-induced endothelin-1 gene expression in rat cardiac fibroblasts. J Am Coll Cardiol 2003;42:1845-54.

15 Cheng JJ, Chao YJ, Wang DL. Cyclic strain activates redox-sensitive prolinerich tyrosine kinase 2 (PYK2) in endothelial cells. J Biol Chem 2002;277:48152-7.

16 Cheng TH, Shih NL, Chen SY, et al. Reactive oxygen species mediate cyclic strain-induced endothelin-1 gene expression via Ras/Raf/extracellular signalregulated kinase pathway in endothelial cells. J Mol Cell Cardiol 2001;33:1805-14.

17 Wung BS, Cheng JJ, Hsieh HJ, et al. Cyclic strain-induced monocyte chemotactic protein-1 gene expression in endothelial cells involves reactive oxygen species activation of activator protein 1. Circ Res 1997;81:1-7.

18 Peng J, Gurantz D, Tran V, et al. Tumor necrosis factor-alpha-induced ATI receptor upregulation enhances angiotensin II-mediated cardiac fibroblast responses that favor fibrosis. Circ Res 2002;91:11119-26.
19 Gardin JM, Wagenknecht LE, Anton-Culver H, et al. Relationship of cardiovascular risk factors to echocardiographic left ventricular mass in healthy young black and white adult men and women. The CARDIA study. Coronary artery risk development in young adults. Circulation 1995:92:380-7.

20 Levy D, Garrison RJ, Savage DD, et al. Prognostic implications of echocardiographically determined left ventricular mass in the Framingham heart study. N Engl J Med 1990;322:1561-6.

21 Hayward CS, Webb CM, Collins P. Effect of sex hormones on cardiac mass. Lancet 2001;357:1354-6.

22 Dubey RK, Gillespie DG, Jackson EK, et al. 17Beta-estradiol, its metabolites, and progesterone inhibit cardiac fibroblast growth. Hypertension 1998:31:522-8.

23 Nuedling S, Kahlert S, Loebbert K, et al. 17 Beta-estradiol stimulates expression of endothelial and inducible NO synthase in rat myocardium in vitro and in-vivo. Cardiovasc Res 1999;43:666-74.

24 Van Eickels M, Grohe C, Cleutjens JP, et al. 17beta-estradiol attenuates the development of pressure-overload hypertrophy. Circulation 2001; 104:1419-23

25 Xin HB, Senbonmatsu T, Cheng DS, et al. Oestrogen protects FKBP12.6 null mice from cardiac hypertrophy. Nature 2002;416:334-8.

26 Lee HW, Eghbali-Webb M. Estrogen enhances proliferative capacity of cardiac fibroblasts by estrogen receptor- and mitogen-activated protein kinase-dependent pathways. J Mol Cell Cardiol 1998;30:1359-68.

27 Grohe C, Kahlert S, Lobbert K, et al. Effects of moexiprilat on oestrogenstimulated cardiac fibroblast growth. Br J Pharmacol 1997;121:1350-4.

28 Mercier I, Colombo F, Mader S, et al. Ovarian hormones induce TGF-beta(3) and fibronectin mRNAs but exhibit a disparate action on cardiac fibroblast proliferation. Cardiovasc Res 2002;53:728-39.

29 Nickenig G, Strehlow K, Wassmann S, et al. Differential effects of estrogen and progesterone on $\mathrm{AT}(1)$ receptor gene expression in vascular smooth muscle cells. Circulation 2000;102:1828-33.

30 Shih NL, Cheng $\mathrm{TH}$, Loh $\mathrm{SH}$, et al. Reactive oxygen species modulate angiotensin II-induced beta-myosin heavy chain gene expression via Ras/ Raf/extracellular signal-regulated kinase pathway in neonatal rat cardiomyocytes. Biochem Biophys Res Commun 2001;283:143-8.

31 Tanaka K, Honda M, Takabatake T. Redox regulation of MAPK pathways and cardiac hypertrophy in adult rat cardiac myocyte. J Am Coll Cardiol 2001;37:676-85

32 Krishnamurthi K, Verbalis JG, Zheng W, et al. Estrogen regulates angiotensin AT1 receptor expression via cytosolic proteins that bind to the $5^{\prime}$ leader sequence of the receptor mRNA. Endocrinology 1999;140:5435-8.

\section{ELECTRONIC PAGES}

\section{Heart Online case reports: www.heartjnl.com}

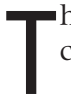

he following electronic only articles are published in conjunction with this issue of Heart.

\section{Coronary air embolism treated with aspiration catheter}

M S Patterson, F Kiemeneij

Coronary air embolism remains a recognised complication of coronary catheterisation despite a strong emphasis on prevention. Current treatment consists of supportive measures with 100\% oxygen and analgesia. Recent case reports describe the use of mechanical treatments aimed at dispersing or removing the air embolus with variable success. A case of coronary air embolism causing an acute coronary syndrome is described that was definitively treated with an aspiration system. The effectiveness of the aspiration system in the distal section of an obtuse marginal artery indicates that such dedicated aspiration systems may prove useful in the standard treatment of air embolism.

(Heart 2005;91:e36) www.heartjnl.com/cgi/content/full/9l/ $5 / \mathrm{e} 36$
Vasculitis masquerading as aortic valve endocarditis M B lqbal, Ni G Fisher, K M Fox

Small vessel vasculitis and endocarditis can both present with multisystem involvement and may present a diagnostic dilemma. Renal and cardiac involvement is common in small vessel vasculitis and rarely small vessel vasculitis may cause heart block. When a patient presents with diffuse symptoms, deteriorating renal function, and heart block, endocarditis and vasculitis should be included in the differential diagnosis. The case is discussed of a man with a history of aortic valve endocarditis who presented again with similar symptoms, deteriorating renal function, and heart block. There was no evidence of aortic valve endocarditis with abscess formation. A renal biopsy confirmed small vessel vasculitis and the patient responded promptly to immunosuppressive treatment. Correct diagnosis is essential in such cases, as immunosuppression in true endocarditis can be catastrophic. In this case, with the correct diagnosis, immunosuppression proved life saving and prevented erroneous aortic valve surgery.

(Heart 2005;91:e37) www.heartjnl.com/cgi/content/full/91/ $5 / \mathrm{e} 37$ 